\title{
Effect of Two Cutting Heights, Four Harvest Intervals and Five Nitrogen Rates on Yield and Composition of Congo Grass under Humid Tropical Conditions ${ }^{1,2}$
}

\author{
José Vicente-Chandler, Servando Silva, Fernando Abruña, and José \\ A. Rodriguez ${ }^{3}$
}

\section{INTRODUCTION}

The effect of cutting heights, harvest intervals, and nitrogen fertilization on yields and composition of Napier, Guinea, Para, Pangola, and Star grasses have been determined under humid tropical conditions in Puerto Rico by Vicente-Chandler, Caro, Figarella, and Silva $(1,2,3,4,5,6,7,8)$. However, there has been little research on the effect of these factors on yield and composition of Congo grass (Brachiaria ruziziensis) under these conditions.

Congo grass can be propagated from cuttings, as are Pangola, Star, Napier, and Para grasses, or from seed which can markedly simplify its establishment. Although Congo grass flowers profusely in Puerto Rico during January and February, it apparently does not produce viable seed which must be imported from other areas, usually Australia. Congo grass is very resistant to attack by the sugarcane aphid, a major pest of Pangola, and is immune to the stunt disease which severely affects Pangola grass in many countries.

The present study determined the effect of cutting heights, harvest interval, and nitrogen fertilization on yield and composition of Congo grass under humid tropical conditions in the mountain region of Puerto Rico.

\section{MATERIALS AND METHODS}

The experiment was conducted through 2 consecutive years at the Corozal Substation of the Agricultural Experiment Station, College of Agricultural Sciences, Mayaguez Campus, University of Puerto Rico. This

1 Manuscript submitted to Editorial Board September 28, 1972.

2 This paper covers work carried out cooperatively between the Soil and Water Conservation Research Division, Agricultural Research Service, USDA, and the Agricultural Experiment Station, College of Agricultural Sciences, Mayagüez Campus, University of Puerto Rico, Río Piedras, P.R.

${ }^{3}$ Soil Scientist-Project Leader, Agricul tural Research Technician, and Soil Scientist, SWCRD, ARS, USDA, and Research Assistant, Corozal Substation, Agricultura] Experiment Station, College of Agricultural Science, Mayagilez Campus, University of Puerto Rico, Río Piedras, P.R., respectively. 
station is located about 700 feet above sea level, with temperatures ranging from $64^{\circ}$ to $89^{\circ} \mathrm{F}$.

The soil is deep, red, acid, moderately-well-drained Corozal clay (Ultisol) on a 20-percent slope. The soil had a $\mathrm{pH}$ of about 5 , an exchange capacity of 12 meq. with 5 meq. of exchangeable bases per $100 \mathrm{~g}$. of soil.

The treatments were tested using a split plot design with 3 replications and a total of 120 plots. Main plots were two cutting heights: 2 or 6 inches from the ground. Subplots were harvest intervals of every $30,45,60$, or 90 days. Sub-subplots were nitrogen rates of $0,200,400,600$, or 800 pounds per acre yearly.

Individual plots, all with a pure stand of Congo grass, were 10 feet $X 15$ feet and were surrounded by ditches to prevent fertilizer from washing into adjoining plots.

The soil in all plots was limed to about $\mathrm{pH} 6.0$ at the start of the experiment. Blanket additions of $\mathbf{1 5 0}$ pounds of $P$ (from triple superphosphate) and 600 pounds of $\mathrm{K}$ (from $\mathrm{K}_{2} \mathrm{SO}_{4}$ ) per acre yearly were applied to all plots. The phosphorus was applied in one annual application and potassium in 4 to 12 equal applications, depending on the harvest interval used. Nitrogen was applied as ammonium sulfate in 4 to 12 applications yearly depending on frequency of cutting.

The grass in the different plots was cut at the prescribed heights and intervals and the forage weighed, sampled, and removed from the plots. All samples were analyzed for dry matter and crude protein. All samples taken during the second year were composited by plots and analyzed for calcium, phosphorus, magnesium, and potassium. Samples from all plots receiving 600 pounds of nitrogen also were analyzed for lignin.

During a season of fast growth (May to August of the first year), forage samples from all plots cut to a height of 2 inches at 60-day intervals and receiving 600 pounds of nitrogen per acre yearly were separated into leaves and stems (including leaf sheath) and analyzed for dry matter, protein, phosphorus, potassium, calcium, and magnesium. Residual yields of forage were taken over an additional 1-year period during which no fertilizer was applied.

\section{RESULTS AND DISCUSSION}

Rainfall was well distributed and totalled 66.87 and 84.44 inches during the first and second years, respectively.

The following tabulation shows the percent dry weight composition of leaves and stems of Congo grass receiving 600 pounds of nitrogen per acre yearly and cut 2 inches above the ground at 60 -day intervals during a period of rapid growth. 


\begin{tabular}{lcc}
\hline & Leaves & Stems + leaf sheaths \\
\hline Proportion & 36.0 & 64.0 \\
Dry matter & 28.6 & 30.2 \\
Crude protein & 9.3 & 4.6 \\
Phosphorus & .15 & .08 \\
Potassium & 2.33 & 1.10 \\
Calcium & .68 & .44 \\
Magnesium & .19 & .16 \\
\hline
\end{tabular}

About one third of the forage consisted of lcaves, which had significantly higher crude protein, phosphorus, potassium, calcium, and magnesium contents than did the stems.

\section{EFFECT OF CUTTING HEIGHT}

Congo grass produced higher yields when cut to a height of about 2 inches from the ground than when cut to 6 inches, at all harvest intervals and nitrogen levels (table 1). Crude protein content of the forage was not appreciably affected by cutting height.

Harvesting the forage every 30 days by cutting to a height of about 6 inches is roughly equivalent to grazing management. With this harvesting procedure, Congo grass responded strongly in yield and protein content to nitrogen applications of up to 400 pounds, producing about 16,000 pounds of dry forage per acre yearly containing 9.7 percent protein. These data indicate that well-managed Congo grass pastures may be capable of carrying three 600-pound steers per acre.

All the following discussion refers to results obtained with low cutting as this harvest procedure gave best results.

\section{EFFECT OF LENGTH OF HARVEST INTERVAL}

Yields of Congo grass increased with length of harvest interval at all nitrogen levels (table 1 and fig. 1). At the 600-pound nitrogen rate, Congo grass produced $23,483,29,554,33,114$, and 45,226 pounds of dry forage per acre yearly when cut every $30,45,60$, and 90 days, respectively.

Crude protein content of the forage decreased with each increase in harvest interval. At the 600-pound nitrogen rate, for example, Congo grass contained $12.3,10.8,8.2$, and 5.0 percent crude protein when cut every 30 , 45,60 , and 90 days, respectively (table 1 ).

Harvest interval did not markedly affect protein yields (table 1) or recovery of fertilizer nitrogen in the forage.

Phosphorus content of the forage decreased sharply with length of harvest interval. At the 400-pound nitrogen rate, for example, phosphorus content of the forage averaged $0.36,0.28,0.19$, and 0.14 percent with a 30 -, 
TABLE 1.-Effect of nitrogen fertilization and frequency and height of cutting on yield and crude prolein content of Congo grass over a 2 -year period at Corozal

\begin{tabular}{|c|c|c|c|c|c|c|c|c|}
\hline \multirow[b]{2}{*}{$\begin{array}{c}\text { Nitro- } \\
\text { gen } \\
\text { ap- } \\
\text { plied } \\
\text { per } \\
\text { acre } \\
\text { yearly }\end{array}$} & \multicolumn{4}{|c|}{ Grass cut to 2 inches from ground } & \multicolumn{4}{|c|}{ Grass cut to 6 inches from ground } \\
\hline & $\begin{array}{l}\text { Yield } \\
\text { of dry } \\
\text { forage } \\
\text { per } \\
\text { acre } \\
\text { yearly }\end{array}$ & $\begin{array}{l}\text { Crude } \\
\text { pro- } \\
\text { tein } \\
\text { con- } \\
\text { tent }\end{array}$ & $\begin{array}{c}\text { Yield } \\
\text { of } \\
\text { crude } \\
\text { protein } \\
\text { per } \\
\text { acre } \\
\text { yearly }\end{array}$ & $\begin{array}{c}\text { Dry } \\
\text { matter } \\
\text { produced } \\
\text { per } \\
\text { pound } \\
\text { of each } \\
\text { incre- } \\
\text { ment } \\
\text { of } N\end{array}$ & $\begin{array}{c}\text { Yield } \\
\text { of dry } \\
\text { forage } \\
\text { per } \\
\text { acre } \\
\text { yearly }\end{array}$ & $\begin{array}{c}\text { Crude } \\
\text { pro- } \\
\text { tein } \\
\text { con- } \\
\text { tent }\end{array}$ & $\begin{array}{c}\text { Yield } \\
\text { of } \\
\text { crude } \\
\text { protein } \\
\text { per } \\
\text { acre } \\
\text { ycarly }\end{array}$ & $\begin{array}{c}\text { Dry } \\
\text { matter } \\
\text { produced } \\
\text { per } \\
\text { pound } \\
\text { of each } \\
\text { incre- } \\
\text { ment } \\
\text { of } N\end{array}$ \\
\hline Pounds & Pounds & Percent & Pounds & Pounds & Pounds & Percenl & Pounds & Pounds \\
\hline \multicolumn{9}{|c|}{ Grass cul every $\$ 0$ days } \\
\hline $\mathbf{0}$ & 7,724 & 7.4 & 579 & - & 5,597 & 7.2 & 401 & - \\
\hline 200 & 12,707 & 8.0 & 1,042 & 24.9 & 11,789 & 8.4 & 983 & 31.0 \\
\hline 400 & 18,695 & 9.8 & 1,830 & 29.9 & 16,148 & 9.7 & 1,590 & 21.8 \\
\hline 600 & 23,483 & 12.3 & 2,895 & 23.9 & 19,891 & 11.8 & 2,355 & 18.7 \\
\hline 800 & 25,337 & 14.3 & 3,580 & 9.3 & 22,623 & 13.8 & 3,145 & 13.7 \\
\hline \multicolumn{9}{|c|}{ Grass cut every 45 days } \\
\hline 0 & 9,984 & 6.3 & 634 & - & 7,682 & 6.5 & 502 & - \\
\hline 200 & 17,457 & 7.5 & 1,331 & 37.4 & 14,164 & 7.5 & 1,058 & 32.4 \\
\hline 400 & 25,330 & 8.7 & 2,165 & 39.4 & 21,165 & 9.3 & 1,957 & 35.0 \\
\hline 600 & 29,554 & 10.8 & 3,160 & 21.1 & 23,610 & 10.3 & 2,441 & 12.2 \\
\hline 800 & 29,253 & 12.2 & 3,529 & - & 25,612 & 11.7 & 2,994 & 10.0 \\
\hline \multicolumn{9}{|c|}{ Grass cul every 60 days } \\
\hline 0 & 8,587 & 5.3 & 473 & - & 6,153 & 5.4 & 335 & - \\
\hline 200 & 18,687 & $\mathbf{5 . 5}$ & 1,033 & 50.5 & 15,702 & 5.8 & 912 & 47.7 \\
\hline 400 & 27,618 & 6.4 & 1,774 & 44.7 & 22,811 & 6.8 & 1,541 & 35.5 \\
\hline 600 & 33,114 & 8.2 & 2,716 & 27.5 & 24,818 & 8.4 & 2,090 & 10.0 \\
\hline 800 & 30,685 & 10.1 & 3,097 & - & 24,382 & 9.5 & 2,318 & - \\
\hline \multicolumn{9}{|c|}{ Grass cut every 90 days } \\
\hline $\mathbf{0}$ & 14,719 & 4.4 & 641 & - & 13,720 & 4.6 & 629 & - \\
\hline 200 & 31,731 & 4.0 & 1,269 & 85.1 & 26,093 & 4.2 & 1,108 & 61.9 \\
\hline 400 & 44,547 & 5.1 & 2,276 & 64.1 & 30,665 & 5.8 & 1,790 & 22.9 \\
\hline 600 & 45,226 & 5.0 & 2,725 & 3.4 & 30,710 & 6.7 & 2,072 & .2 \\
\hline 800 & 42,289 & 7.2 & 3,056 & - & 31,526 & 7.8 & 2,464 & 4.1 \\
\hline
\end{tabular}

45-, 60-, and 90-day harvest interval, respectively (table 2). A phosphorus content of about 0.20 percent is required for adequate nutrition of most cattle. Potassium content of the forage generally decreased with length of harvest interval, but harvest interval had no appreciable effect on the calcium or magnesium content of the forage.

Lignin content of the forage increased with length of harvest interval as shown by the following tabulation of data from samples taken from all plots receiving 600 pounds of nitrogen per acre during the second year of experimentation. 


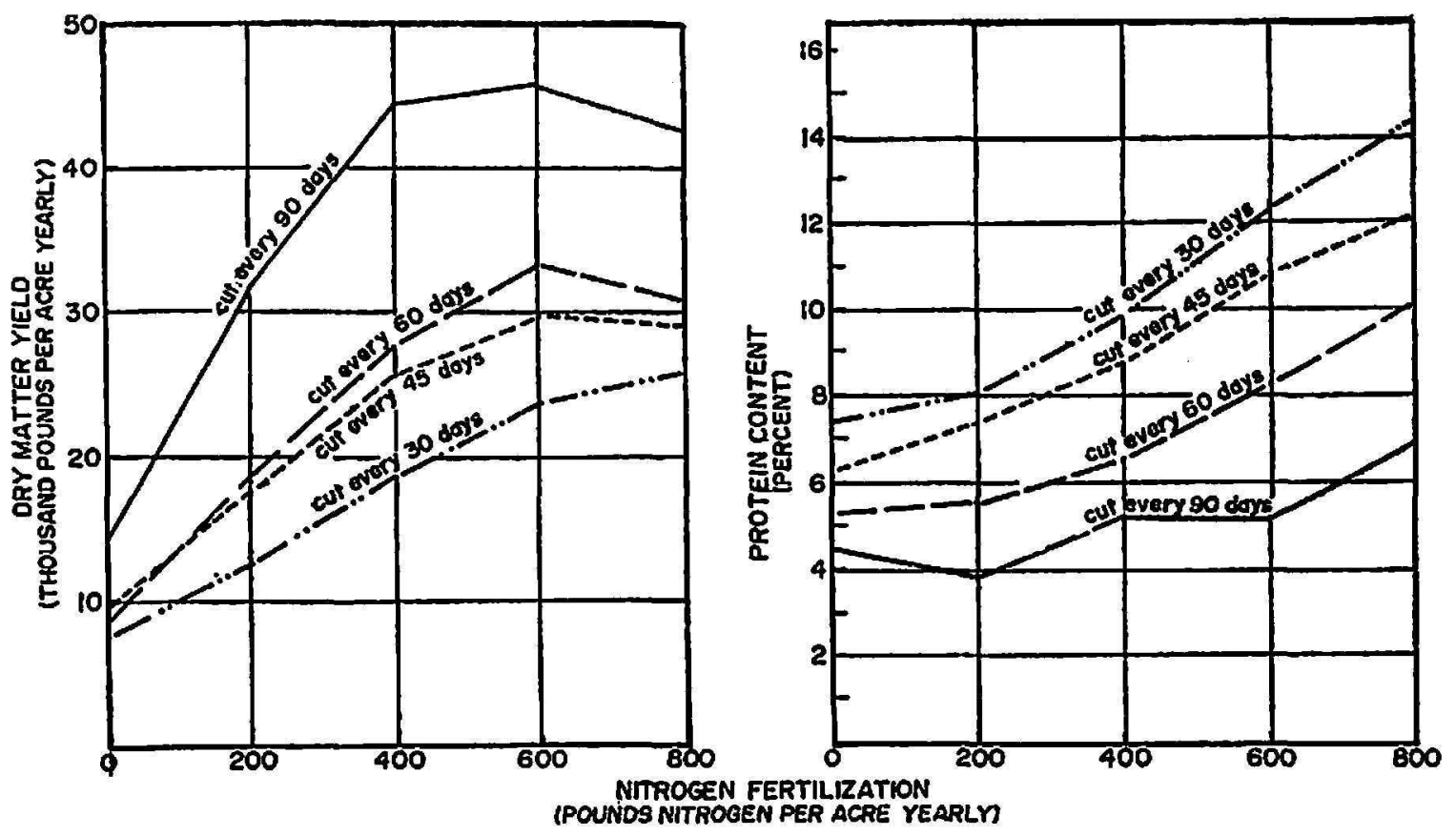

Fig. 1.-Effect of nitrogen fertilization and frequency of cutting on yields and protein content of Congo grass cut to a height of about 2 inches from the ground over a 2-year period at Corozal.

TAHLE 2.-Effect of nitrogen fertilizalion and harvest inlerval on the composition of Congo grass during second year of experimentation at Corozal

\begin{tabular}{cccccc}
\hline \multirow{2}{*}{$\begin{array}{c}\text { Harvest } \\
\text { interval }\end{array}$} & $\begin{array}{c}\text { Nitrogen } \\
\text { applied per } \\
\text { acce yearly }\end{array}$ & \multicolumn{4}{c}{ Composition of forage (dry weight basis) } \\
\cline { 2 - 6 } & Phosphorus & Calcium & Magnesium & Potassium \\
\hline Deys & Pounds & Percent & Percent & Percent & Percent \\
30 & 0 & 0.40 & 0.64 & 0.21 & 2.20 \\
& 200 & .34 & .66 & .17 & 2.81 \\
& 400 & .36 & .60 & .19 & 3.01 \\
& 600 & .25 & .61 & .24 & 2.92 \\
45 & 800 & .28 & .66 & .22 & 2.38 \\
& 0 & .36 & .01 & .28 & 2.13 \\
& 200 & .29 & .65 & .23 & 2.80 \\
& 400 & .28 & .64 & .23 & 2.94 \\
60 & 600 & .24 & .61 & .27 & 2.42 \\
& 800 & .22 & .69 & .21 & 2.32 \\
& 0 & .32 & .71 & .20 & 2.06 \\
& 200 & .19 & .63 & .19 & 2.71 \\
& 400 & .19 & .50 & .30 & 2.42 \\
& 600 & .17 & .67 & .27 & 2.01 \\
90 & 800 & .18 & .68 & .28 & 1.96 \\
& 0 & .20 & .60 & .20 & 1.87 \\
& 200 & .13 & .55 & .19 & 2.10 \\
& 400 & .14 & .51 & .26 & 1.46 \\
& 600 & .13 & .57 & .24 & 1.28 \\
& 800 & .14 & .62 & .27 & 1.65 \\
\hline
\end{tabular}




\begin{tabular}{cc}
\hline Length of harvest interval & Lignin content of forage \\
\hline (Days) & (Percent) \\
30 & 6.8 \\
45 & 7.5 \\
60 & 8.1 \\
90 & 10.3 \\
\hline
\end{tabular}

\section{EFFECT OF NITROGEN FERTILIZATION}

Congo grass responded strongly in yield to nitrogen applications of up to 600 pounds per acre yearly at all harvest intervals (table 1 and fig. 1). With a 90-day harvest interval, heavy applications of nitrogen and potassium concentrated in only four applications yearly caused burning to which Congo grass is particularly susceptible since the rather hairy leaves retain much of the applied fertilizer.

With a 60-day harvest interval, yields of Congo grass were almost quadrupled (from 8,587 to 33,114 pounds of dry forage per acre yearly) by increasing nitrogen rates from 0 to 600 pounds per acre yearly. At this rate of fertilization, an average of 41 pounds of dry forage were produced per pound of fertilizer nitrogen applied.

Assuming 20-percent wastage and 50-percent digestibility of the forage, about 18 pounds of dry Congo grass forage would be required to feed a 600 -pound steer gaining 1 pound daily. Beef on the hoof is worth about 30 cents per pound at current prices, thus every pound of nitrogen fertilizer (worth 15 cents) must produce at least 10 pounds of dry forage to break even on costs. These rough calculations suggest that it is economical to apply up to 600 pounds of nitrogen per acre yearly to Congo grass under the conditions of this experiment.

Congo grass responded strongly in yield to nitrogen fertilization during both seasons of slow and fast growth, although the response was much greater during the latter (fig. 2). For example, during seasons of fast growth, 33.6 pounds of dry forage were produced per pound of nitrogen applied at the 600-pound rate compared to only 16.6 pounds during seasons of slow growth. However, it must be borne in mind that forage is more valuable during the latter season.

Protein content of the forage increased sharply with nitrogen fertilization up to the highest level tested at all harvest intervals (table 1 and fig. 1) and during seasons of both fast and slow growth (fig. 2). With a 60-day harvest interval, protein content of the forage increased from 5.3 to 10.1 percent when nitrogen fertilization was increased from 0 to 800 pounds per acre yearly.

Protein yields increased sharply with nitrogen fertilization at all harvest 
intervals and seasons. With a 60-day harvest interval, protein yields averaged $473,1,033,1,774,2,716$, and 3,097 pounds per acre yearly at the 0 -, $200-, 400-, 600-$, and 800-pound nitrogen rates.

The following tabulation shows that the dry matter content of Congo grass cut every 30 and 60 days over a 2-year period at Corozal decreased with increasing nitrogen rates.

\begin{tabular}{ccc}
\hline \multirow{2}{*}{$\begin{array}{c}\text { Nitrogen } \\
\text { applied per } \\
\text { acre yearly }\end{array}$} & \multicolumn{2}{c}{ Dry matter content of forage } \\
\cline { 2 - 3 } & Cut every 30 days & Cut every 60 days \\
\hline (Pounds) & (Percent) & (Percent) \\
0 & 26.4 & 28.2 \\
200 & 24.0 & 25.4 \\
400 & 21.9 & 24.0 \\
600 & 20.7 & 23.1 \\
800 & 21.8 & 22.1 \\
\hline
\end{tabular}

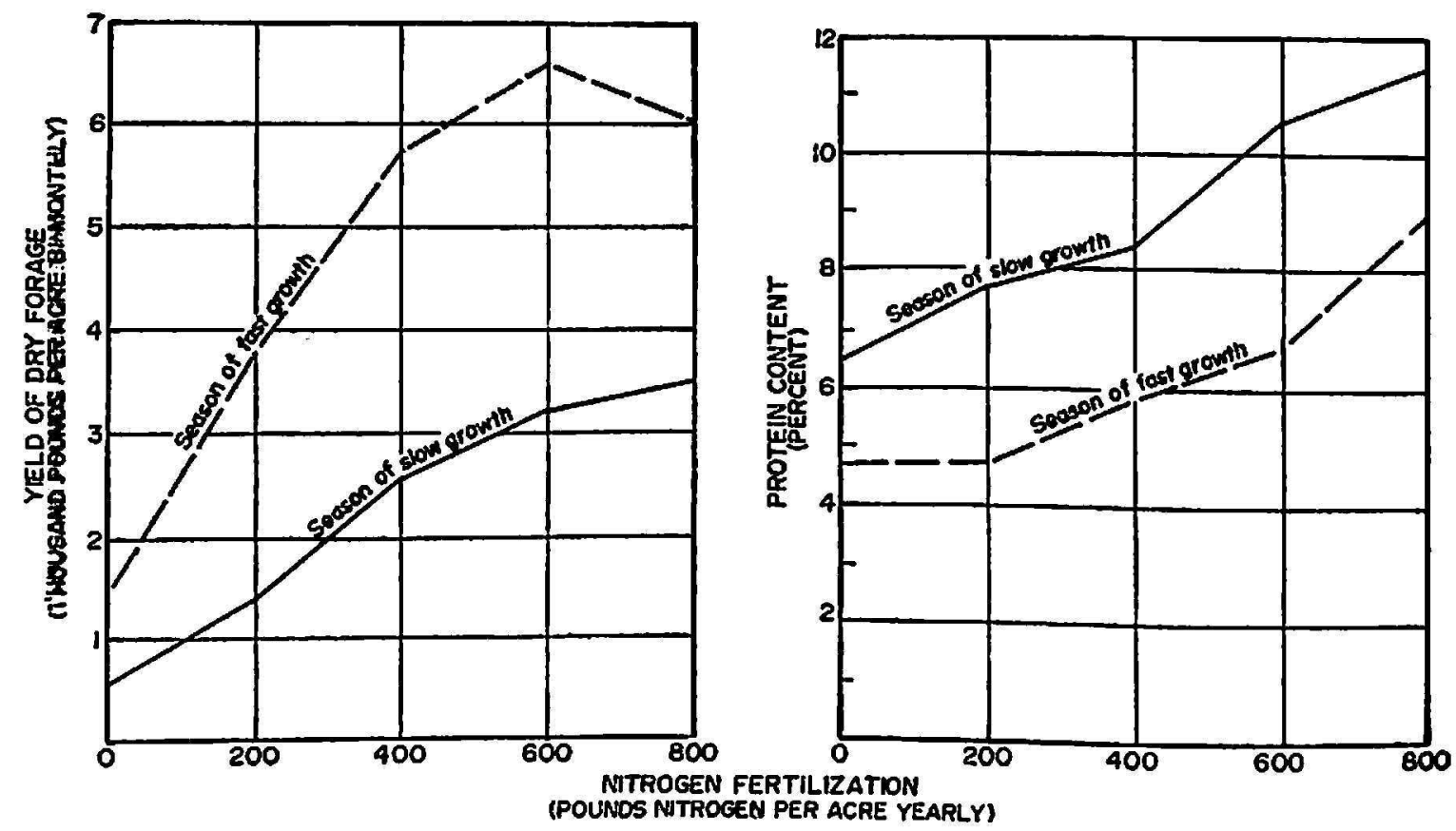

Fig. 2.-Response of Congo grass cut every 60 days to nitrogen fertilization during seasons of slow (November-February) and fast (May-August) growth over a 2-year period at Corozal.

This decrease in dry matter content could result in a decrease in the quantity of dry forage ingested daily by grazing cattle.

The overall high dry matter content of young Congo grass is noteworthy. When cut every 30 days and fertilized with 400 pounds of nitrogen, Congo grass had an average dry matter content of 21.9 percent compared to $\mathbf{1 5 . 2}$ percent reported by Vicente-Chandler et al. (6) for similarly treated Pangola grass 
Recovery of fertilizer nitrogen in the forage was higher at the 400 - and 600 - than at the 200-pound nitrogen level and averaged 60 percent at the 600 -pound nitrogen rate. There was little residual nitrogen carried over in the soil (table 3 ).

Phosphorus content of the forage generally decreased with increasing nitrogen fertilization (table 2). With a 60-day harvest interval, for exam-

TABLE 3.-Recovery of fertilizer nilrogen by Congo grass al Corozal as affected by nitrogen rales. Values are averages for all harvest intervals and a 2-inch culting height

\begin{tabular}{ccc}
\hline $\begin{array}{c}\text { Nitrogen applied } \\
\text { per acre yearly }\end{array}$ & \multicolumn{2}{c}{ Recovery of fertilizer nitrogen in forage } \\
\cline { 2 - 3 } & $\begin{array}{c}\text { During 2 years of } \\
\text { experimentation }\end{array}$ & $\begin{array}{c}\text { During residual } \\
\text { 1-year period }\end{array}$ \\
\hline Pounds & Percent & Percent \\
0 & - & - \\
200 & 47.1 & - \\
400 & 57.5 & 1.4 \\
600 & 60.0 & 3.6 \\
800 & 54.7 & 5.4 \\
\hline L.S.D.05 & 4.4 & - \\
\hline
\end{tabular}

TABLE 4.-Effecl of nilrogen fertilization on removal of nutrients in Congo grass forage cul every 45 days over the second year of experimentation al Corozal

\begin{tabular}{cccccc}
\hline $\begin{array}{c}\text { Nitrogen } \\
\text { fertilization } \\
\text { per acre yearly }\end{array}$ & $\begin{array}{c}\text { Yields of dry } \\
\text { forage per } \\
\text { acre yearly }\end{array}$ & \multicolumn{3}{c}{ Nutrients removed in forage per acre yearly } \\
\cline { 5 - 7 } & Poutassium & Phosphorus & Calcium & Magnesium \\
\hline Pounds & Pouss & Posinds & Pounds & Pounds & Pozinds \\
0 & 7,682 & 199 & 34 & 57 & 26 \\
200 & 14,164 & 400 & 41 & 91 & 32 \\
400 & 21,165 & 619 & 58 & 135 & 48 \\
600 & 23,610 & 619 & 65 & 155 & 69 \\
800 & 25,612 & 601 & 57 & 178 & 53 \\
\hline
\end{tabular}

ple, phosphorus content of the forage decreased from 0.32 to 0.18 percent when nitrogen rates were increased from 0 to 800 pounds per acre yearly. Nitrogen fertilization had no consistent effect on the magnesium, potassium, or calcium content of the forage.

Nitrogen fertilization drastically increased removal of nutrients in the forage (table 4). Increasing nitrogen rates from 0 to 800 pounds per acre yearly with a 45-day harvest interval increased removal of nutrients expressed as pounds per acre yearly, as follows: Nitrogen, 199 to 601; phosphorus, 34 to 57 ; calcium, 57 to 178; and magnesium from 26 to 53. 


\section{EFFECT OF SEASON OF THE YEAR}

Congo grass produced lowest yields during November, December, January, and February (fig. 3). Although lower rainfall was a factor in decreasing yields during this season, the shorter days and cooler weather, as well as the fact that Congo grass flowers profusely during January and February, were probably of greater importance.

Higher yields were produced during all seasons of the year with a 60than with a 30-day harvest interval (fig. 3).

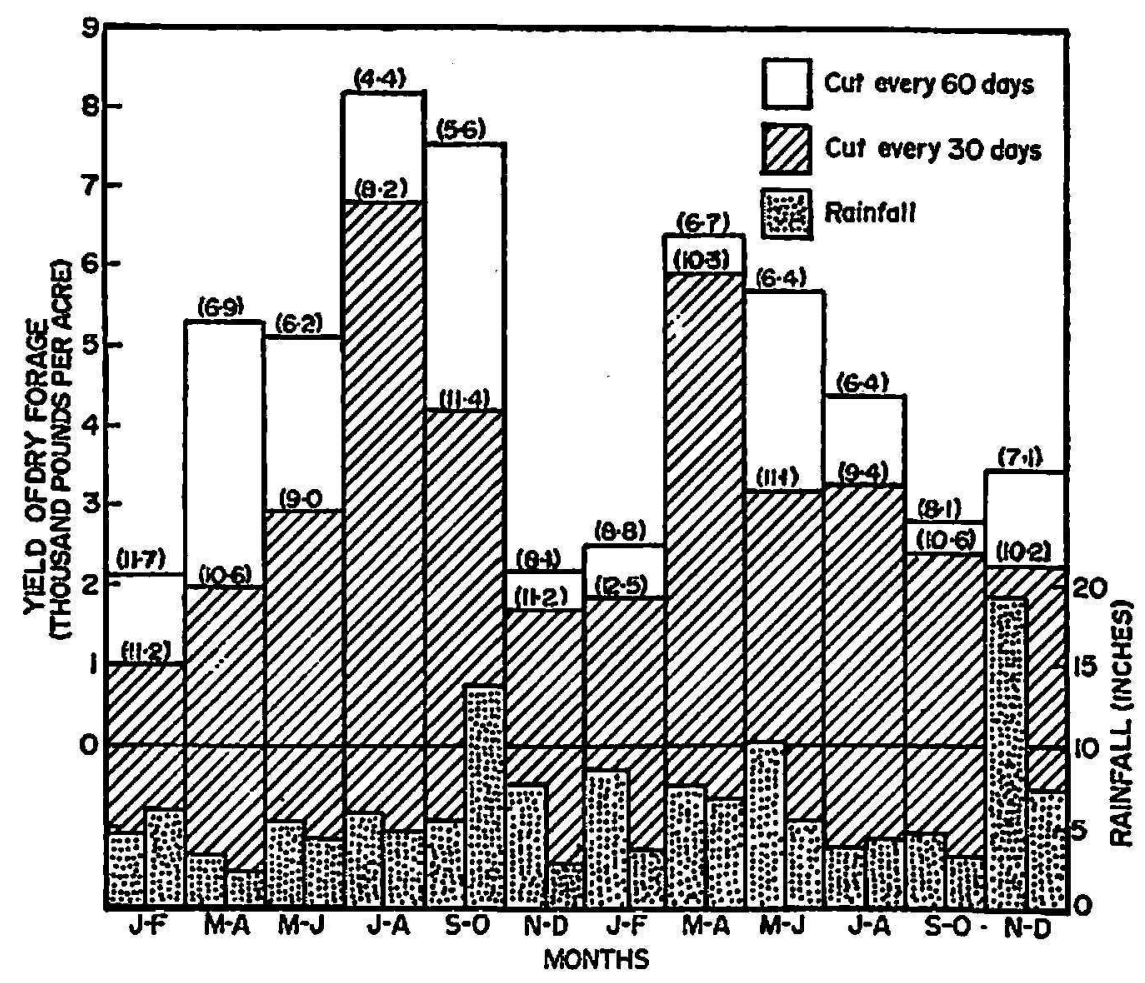

Fia. 3.-Effect of season of the year on yields of Congo grass receiving 400 pounds of nitrogen per acre yearly and harvested at 2 intervals over a 2-year period at Corozal. Numbers in parenthesis show protein content of the forage.

Crude protein content of the forage was higher during seasons of slow growth and lower during seasons of fast growth (figs. 2 and 3), probably as a result of the concentrating and diluting effects, respectively, of yields in the presence of similar levels of nitrogen in the soil.

Seasonal fluctuations in growth can be reduced by using a longer harvest interval and applying more nitrogen to increase yields during seasons of slow growth (figs. 2 and 3).

It would appear best to fertilize Congo grass harvested for green chop feed with 600 pounds of nitrogen per acre yearly and to cut the grass to a height of about 2 inches from the ground about every 45 days during seasons of fast growth and every 60 days during periods of slow growth (fig. 4). 


\section{SUMMARY}

The effect of cutting to heights of 2 and 6 inches from the ground, of harvesting every $30,45,60$, and 90 days, and of applying $0,200,400,600$, and 800 pounds of nitrogen per acre yearly on yields and composition of Congo grass, were determined under humid tropical conditions over a 2-year period.

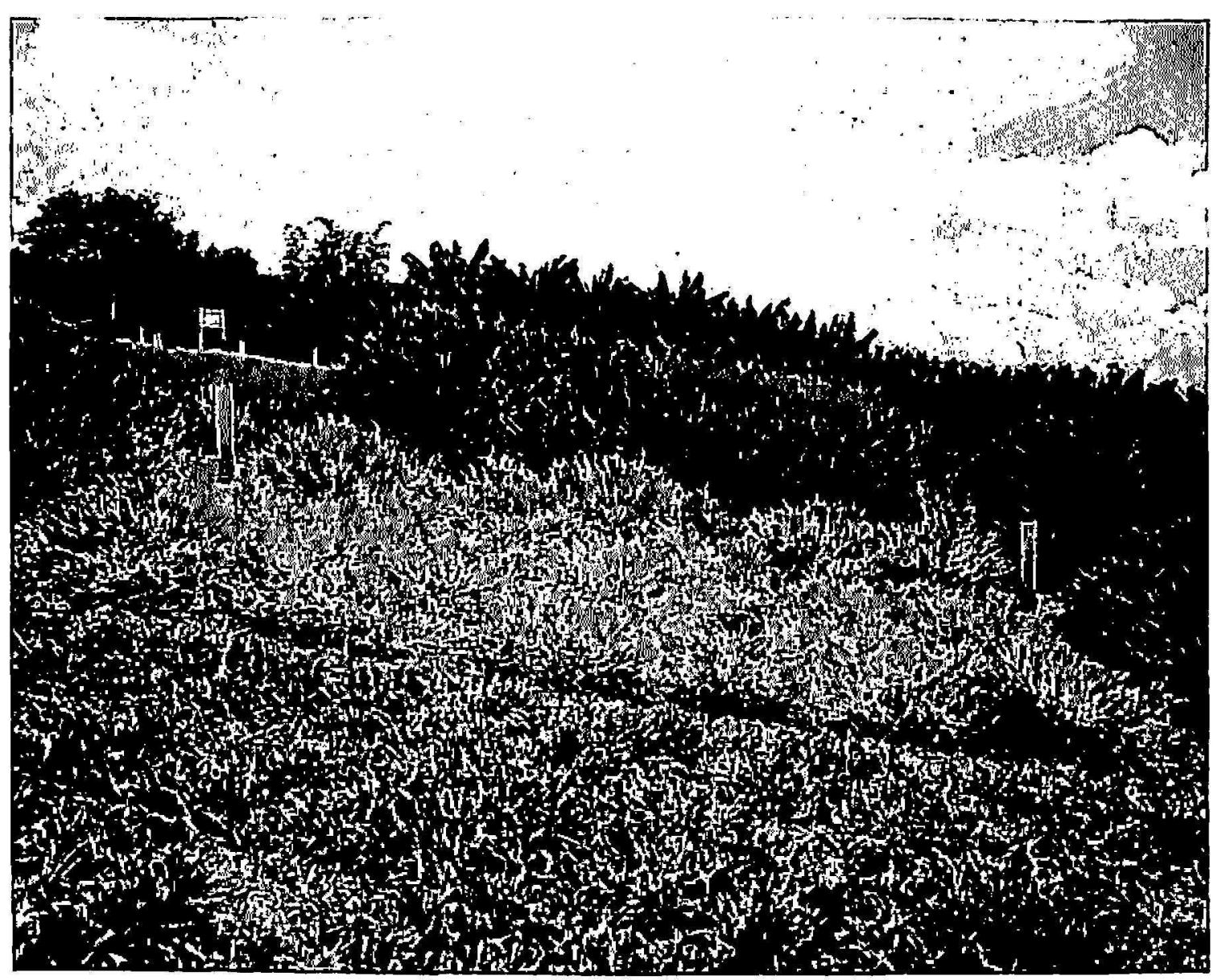

Fig. 4.-Congo grass cut to a height of about 2 inches from the ground every 45 to 60 days responds strongly to nitrogen applications of up to 600 pounds per acre yearly. Otherwise well-fertilized grass in foreground received no nitrogen; that in background received 600 pounds of nitrogen per acre yearly. Congo grass managed in this manner produced about 30,000 pounds of dry forage per acre yearly containing 9.5 percent of crude protein.

Congo grass produced higher yields when cut to a height of 2 inches than when eut to 6 inches, at all harvest intervals and nitrogen rates. The following discussion is therefore limited to results obtained with low cutting.

Yields of Congo grass increased, but crude protein content of the forage decreased with increasing length of harvest interval. Harvest interval did not markedly affect protein yiclds. Phosphorus and potassium content of the forage decreased with increasing length of harvest interval but the 
calcium and magnesium content were not affected. Lignin content of the forage increased with increasing length of harvest interval.

Yields of Congo grass increased with nitrogen application up to 600 pounds per acre yearly at all harvest intervals and during seasons of both fast and slow growth.

Protein content of the forage and protein yields increased with nitrogen rates up to 800 pounds per acre yearly.

Recovery of fertilizer nitrogen in the forage averaged about 60 pereent at the 600-pound nitrogen rate.

Dry matter and phosphorus content of the forage decreased with increased nitrogen fertilization. Nitrogen fertilization did not affect the calcium, magnesium, or potassium content of the forage.

Much lower yields were produced during the shorter days and cooler, drier winter months.

With close cutting every 45 to 60 days and 600 pounds of nitrogen applied per acre yearly, Congo grass produced about 30,000 pounds of dry forage ( 65 tons of green forage) containing 9.5 percent protein, or enough cut forage to feed over five 600-pound steers per acre. With high cutting every 30 days, which may approximate yields under grazing management, Congo grass fertilized with 400 pounds of nitrogen per acre yearly produced about 16,000 pounds of dry forage per acre yearly containing 9.7 pereent of protein.

\section{RESUMEN}

Se determinó, durante un periodo de 2 años, el efecto de cosechar la yerba Congo, cada $30,45,60$ y 90 días, cortándola a 2 y a 6 pulgadas de altura, y aplicándole 0,200 , 400,600 y 800 libras de nitrógeno por acre al año, en su producción y composición.

Los rendimientos fueron mayores cuando la yerba Congo se cortó a 2 que a 6 pulgadas del suelo. Por lo tanto, la siguiente discusión se circunseribe a los datos obtenidos al cortarse a unas 2 pulgadas del suelo.

La producción de la yerba aumentó según se alargó el intervalo entre los cortes. Por el contrario, el contenido en proteína del forraje disminuyó, aunque no afectó la producción total de proteína por acre.

También disminuyó el contenido de fósforo y de potasio de la yerba Congo al alargarse el período entre los cortes, pero no se afectó el contenido de calcio y de magnesio. El contenido de lignina de la yerba aumentó al alargarse el período entre los cortes.

La producción de forraje aumentó con las aplicaciones de nitrógeno hasta que estas aleanzaron 600 libras por acre al año, con todos los intervalos entre corte $y$ durante las épocas de crecimien to rápido y las de crecimient o lento.

El contenido de proteína del forraje y la producción total de proteína aumentaron marcadamente al aumentarse las aplicaciones de nitrógeno hasta alcanzar 800 libras por acre al año.

En el forraje se recobró aproximadamente el 60 por ciento del nitrógeno aplicado cuando la yerba se abonó con 600 libras por acre al año. 
El contenido de materia seca y de fósforo en el forraje disminyú al aumentarse los niveles de nitrógeno, pero esto no afectó el contenido de calcio, magnesio o potasio.

La producción de forraje fue mucho menor durante los meses de invierno cuando los días son más cortos, la temperatura más baja y la lluvia menos abundante.

A base de estos resultados se recomienda cortar la yerba Congo aproximadamente a 2 pulgadas del suelo cada 45 días durante épocas de crecimiento rápido y cada 60 días durante épocas de poco crecimiento y abonarla con 600 libras de nitrógeno por acre al año. Este tratamiento produjo unas 30,000 libras de forraje seco por acre al año con un contenido de 9.5 por ciento de proteína, cantidad suficiente para alimentar cinco novillos de 600 libras de peso cada uno durante un año.

\section{LITERATURE CITED}

1. Caro-Costas, R., Abruña, F., and Figarella, J., Effect of nitrogen rates, harvest interval, and cutting heights on yield and composition of Star grass in Puerto Rico, J. Agr. Univ. P.R. 56 (3): 267-79, 1972.

2. Caro-Costas, R. and Vicente-Chandler, J., Effect of two cutting heights on yields of 5 tropical grasses, J. Agr. Univ. P.R. 45 (1): 46-49, 1961.

3. Caro-Costas, R. and Vicente-Chandler, J., Effect of fertilization on carrying capacity and beef produced by Napier grass pastures, Agron. J., 53 (3): 204-5, 1861.

4. Caro-Costas, R., Vicente-Chandler, J., and Figarella, J., The yield and composition of five grasses growing in the humid mountains of Puerto Rico as affected by nitrogen fertilization, season, and harvest procedure, J. Agr. Univ. P.R. 44 (3) : 107-20, 1960.

5. Vicente-Chandler, J. and Figarella, J., The effect of five nitrogen sources on yield and composition on Napier grass, J. Agr. Univ. P.R. 46 (2): 102-6, 1962.

6. Vicente-Chandler, J., Figarella, J., and Silva, S., Effects of nitrogen fertilization and frequency of cutting on the yield and composition of Pangola grass in Puerto Rico., J. Agr. Univ. P.R., 45 (1): 37-45, 1961.

7. Vicente-Chandler, J., Silva, S., and Figarella, J., The effort of nitrogen fertilization and frequency of cutting on the yield and composition of three tropical grasses, Agron. J. 51: 202-6, 1959.

8. - Effect of frequency of application on response of Guinea grass to nitrogen fertilization, J. Agr. Univ. P.R. 46 (4) : 342-9, 1962. 